Ophthal. Res. 1972;3:I-VII

\title{
Contents, Vol. 3, 1972
}

\section{Contents}

Benson, Ch. : vide O'Rourke, J.

Bloom, A.;Heath, H.;Kelsey, J.J.; Hunter, P.R. andBRiGøEN, W.D. (London):

The Use of the Roth-Keeler Central Field Scotometer in the Study of Dia

betic Retinopathy

166

Boeck, H.: vide Reim, M.

Bours, J.: vide Doorenmaalen, W. J. van

Brigden, W.D.: vide Bloom, A.

Brihaye, M. and Oosterhuis, J.A. (Amsterdam/Brussels/Leyden): Experimental

Cryoapplication with Variations in the Pressure Exerted on the Sclera . 129

Buschmann, W.: vide Herrmann, G.

Cambie, E.: vide Francois, J.

Cejková, J.: vide Obenberger, J.

Clark, F.: vide Holland, M.G.

Cremer-Bartels, Gertrud ; Hockwin, O. and Schedtler, Christa-M aria (Bonn):

The Problem of Fluorescence of Human Cataractous Lenses 122

Crotty, M.W.: vide Reddan, J.R.

Deyl, Z.: vide Sulcová, H.

Doorenmaalen, W.J. van and Bours, J. (Utrecht): Lens and Development; Ab

stracts of the Lens Symposium, Utrecht August 23-26, 1971

Durrani, J.: vide O'Rourke, J.

Elewaut-Rysselaere, M.: vide Francois, J.

Francois, J. and Cambie, E. (Ghent): Collagenase and the Collagenase Inhibitors

in Torpid Ulcers of the Cornea 145

Francois, J. and Elewaut-Rysselaere, M. (Ghent): Ocular Infections Due to

Gram-Negative and Non-Fermentative Microorganisms $\quad 1.14$

Freeman, N. vide Reddan, J. R.

Friedburg, D. (Düsseldorf): Enzyme Activity Patterns and some Intermediates in Human Senile Cataract 224

Gnädinger, M. C. (Basel): Synthesis of Hydroxyproline in Corneal Epithelium. . 198

Hanna, C. and Sanchez, J. (Little Rock, Ark.): Effects of Acetazolamide on Con centration of Free Amino Acids in Aqueous Humor 283

Harding, C. V.: vide Reddan, J. R.

Hasselt, P. van (Nijmegen): Effects of Ablation of Visual Cortical Areas and Optic

Nerve Section upon the Double-Flash Electroretinogram of the Cat . . 83

Hasselt, P. van (Nijmegen): The Effects of Ablation of Visual Cortical Areas on the

Electroretinogram of the Cat 160

Heath, H.: vide Bloom, A. 
Heimann, K. (Cologne): The Development of the Choroid in Man. Choroidal Vas cular System 257

VI Contents

Heisig, B.: vide Rüssmann, W.

Herrmann, G. and Buschmann, W. (Berlin): Methods for Measuring the HF Oscil lation Frequency in Ultrasound Pulses of Equipment for Diagnostic

Ultrasonography 274

Hirano, H.: vide Ono, S.

Hockwin, O. (Bonn): Preface to journal no.6 of volume 3321

Hockwin, O.: vide Cremer-Bartels, Gértrud

Hoffmann, F. (Berlin): The Surface of Epithelial Cells of the Cornea under the

Scanning Electron Microscope 207

Hohorst, H.J.: vide Schmidt-Martens, F.W.

Holland, M. G. and Clark, F. (New Orleans, La.): An Automatic Measuring and

Recording System for Clinical Electro-Oculography 311

Huber, C. (Bad Nauheim): Visual Evoked Responses during Exposure to strong

Colored Lights 55

Hunter, P. R.: vide Bloom, A.

Jones, H.A.: vide Lerman, $\mathrm{S}$.

Juricová, M.: vide §ulcová, H.

Kelsey, J. H.: vide Bloom, A.

Krejci, L. (Prague): Changes of $\mathrm{pH}$ Associated with Experimental Trauma and Acute Elevation of Intraocular Pressure

193

Krug, P.: vide Reim, M.

Lee, P.: vide Reddan, J.R.

Lerman, S.; Mehta, P. and Jones, H.A. (Montreal): The Re-Aggregation of AlphaCrystallin $\quad 30$

Manski, W.: vide York, A. T.

Maraini, G. and Pescatori, A. (Parma): Changes in Weight and in Protein - Water

Ratio of the Lens in Human Senile Cataracts 108

Martinez, C.: vide York, A. T.

Mehta, P.: vide Lerman, $\mathrm{S}$.

Nordmann, J. (Strasbourg): Problems in Cataract Research 323

Obara, K.: vide Ono, S.

Obenberger, J. and Cejková, J. (Prague): Experimental Corneal Calcification. Role ofEpithelium 174

Ono, S.; Hirano, H. and Obara, K. (Morioka): Presence of Cortisol-Binding Pro

tein in the Lens 233

Ono, S.; Hirano, H. and Obara, K. (Morioka): Study on the Conjugation of Cortisol in the Lens 307

Oosterhuis, J.A.: vide Brihaye, M.

O'Rourke, J.; Durrani, J. and Benson, Ch. (Hartford, Conn.): Uveoretinal Uptake of $69 \mathrm{~m} \mathrm{Zn}$. Studies in the Cat Eye as a Basis for Desing of Clinical Tests . . 289

Pescatori, A.: vide Maraini, G.

Popp, M.: vide Shipley, T.

Praus, R.: vide §ulcová, $\mathrm{H}$. 
Reddan, J. R.; Harding, C.V.; Rothstein, H.; Crotty, M.W.; Lee, P. and Free man, N. (Rochester, Mich./Burlington, Vt.): Simulation of Mitosis in the Vertebrate Lens in the Presence of Insulin 65

\section{Contents VII}

Reim, M.; Boeck, H.; Krug, P. and Venske, G. (Marburg): Aqueous Humor and Cornea Stroma Metabolite Levels under Various Conditions

Rosenbaum, D.M. and Rothstein, H. (Burlington, Vt.): Mitotic Variations in the Lens Epithelium of the Frog 95

Rosmus, J. vide Sulcová, H.

Rothstein, H.: vide Redd an, J. R.

Rothstein, H.: vide Rosenbaum, D.M.

Rüssmann, W. and Heisig, B. (Cologne): Analogy and Difference in Ciliary Process

Enzyme Systems 215

Sanchez, J.: vide Hanna, C.

Schedtler, Christa-Maria: vide Cremer-Bartels, Gertrud

Schimmel, K. P.: vide Welge-Lüssen, L.

Schmidt-Martens, F. W. and Hohorst, H. J. (Marburg/Lahn): Free Fatty Acids in

Bovine Cornea and Corneal Epithelium (Short-Communication) .... 126

Shipley, T. and Popp, M. (Miami, Fla.): Stereoscopic Acuity and Retinal Eccen tricity 251

Stefani, F. H. (Munich): Further Studies on 'Aberrant' Ganglion Cells in the Human Oculomotor Nerve 46

Sulcová, H.; Praus, R.; Deyl, Z.; Juricová, M. and Rosmus, J. (Prague). Comparative Studies on Collagens from Bovine and Calf Cornea and Skin . 298

Venske, G.: vide Reim, M.

Weiss, H. (Vienna): The Carbohydrate Reserve in the Vitreous Body and Retina of the Rabbit's Eye during and after Pressure Ischaemia and Insulin Hypoglycaemia 360

Welge-Lüssen, L. and Schimmel, K.P. (Marburg/Lahn): Concentration of Amino Acids in the Vitreous after Intravitreal Injection of Ascorbic Acid ... 38

York, A. T.; Martinez, C. and Manski, W. (New York, N.Y.): Immunochemical

Studies on Crystallins and Albuminoids in Human Senile Cataracts . 183

Varia 63, 192, 256, 372 